\title{
A WHITE MIST IN THE BLACK UNISA
}

\author{
Tumi Senokoane \\ Discipline of Theological Ethics
}

Unisa

\begin{abstract}
The academic institutions in South Africa are systematically and structurally white. In short, shades of white ethics blight academic institutions such as Unisa. This article, therefore, aims to expose the argument that Unisa is still excluding black academics on the basis of race. Black academics are directly and indirectly subjected to institutional racism, which dramatically undermines their chances of academic success. Institutional racism, otherwise known as white ethics, positions itself as a standard or norm in the institution and at the same time places itself as the only good, and other experiences and knowledge as bad and does not meet the standard. The article will argue in contrast that blackness and black experience and knowledge should be placed as the good and whiteness as bad, thereby calling for black ethics.
\end{abstract}

Key Words: Ethics; Exclusion; Institutional Racism; Worldview; Revolution

\section{Introduction}

This article is a result of the Round Table Ethics discussions that are organised by the ViceChancellor and Principal of the University of South Africa (Unisa), Prof Mandla Makhanya, and which I was invited to present. On 6 June 2014 an invitation was sent via Unisa's Intcom, and my title read, "A white mist in the black Unisa". On the same day Dr Jeanette Botha (Director in the Office of Principal and Vice-Chancellor at Unisa) phoned me asking if I had the right topic, to which I responded that I did. The Intcom was removed and replaced with the topic, "Whose ethics should define our conduct at Unisa?" This was the topic that was included in my invitation. I had asked Prof Divya Singh (Vice-Principal of Advisory and Assurance Services at Unisa) what exactly I should talk about, and eventually I asked her to give me a 'blank cheque', which she agreed to do. Moreover, the invitation had a question that I had to engage with and try to answer: "Whose ethics should define our conduct at Unisa?" The title I chose was a direct answer to this question; my answer is that "black ethics should determine our conduct at Unisa". I must reiterate that the question was never mine, but that of Unisa. Oliver Goldsmith said: "Ask me no question, and I'll tell you no truth". But if you ask me a question, I'll tell you the truth, because "I want to be an honest man and a good writer" (Baldwin, 2014). I have since asked myself if this invitation was a mistake, a failure to investigate who had been invited. But I said to myself: if indeed it was a mistake, I have learnt from Napoleon that you should "never interrupt your enemy when he [or she] is making a mistake".

Let me introduce myself to the readers. I am a black theologian and a black ethicist. Black theology is a theological perspective found in some black churches that contextualises Christianity in an attempt to help blacks overcome oppression. It seeks to liberate black people from multiple forms of political, social, economic and religious subjugation. "Black Theological Ethics is preoccupied with liberation. It is concerned about meaning, 
survival, and protest for a people despised and degraded" (Roberts Sr., 1975:71). I am a thermostat, as distinguished by Cornell West (2011) saying: "You've got to be a thermostat rather than a thermometer. A thermostat shapes the climate of opinion; a thermometer just reflects it."

\section{Whose Definition and Territory?}

The querying, removal and change of my title exposed the very issue of "whose ethics define our conduct at Unisa". White ethics tells us what is good or bad, right or wrong. It tells us what to think and what not to think, or what to write and what not to write. Toni Morrison (2014) said: "In this country American means white. Everybody else has to hyphenate." But I consciously and subconsciously refuse this worldview with its impositions. And I do this with a full understanding that "the power of the white world is threatened whenever a black man refuses to accept the white world's definitions" (Baldwin in Lock, 1999:119). My article, therefore, positions itself as a dynamite message to the white world. In the words of Steve Biko in his letter to the SRC, "the blacks are tired of standing at the touchlines to witness a game that they should be playing" (Biko, 1978:15). By playing the game blacks must avoid the trap of normalising white ethics, as Boesak (1984:17) argues:

White values shall no longer be thought of as 'the highest good'. Blacks shall no longer hate themselves in terms of others. They shall, rather, move toward their own authentic blackness out of their Negroid and nonwhite character. In this way they shall force whites to see themselves in their whiteness and to perceive the consequences of this whiteness for others.

We must remember that coloniality survives colonialism and whiteness survives apartheid. Normalising is enshrined in neutrality. The system (which I prefer to call isandla se-mfene - literal translation meaning 'monkey's hand' but interpreted as 'underhandedness') is portrayed as neutral, universal and as a standard. White knowledge positions itself as universal and thereby makes us keep the very same structure that has oppressed us. Blacks are, therefore, challenged to decolonise universities to avoid being alienated from themselves. Blacks must dare to construct alternatives, substituting the oppressor's order with a full understanding that the order was not a coincidence. As Gutierrez (1979:117) argues: "... we all know that this does not happen 'unfortunately', but that it is the fault of the system itself, due not to 'neglect' but to the very logic of the system."

The construction of knowledge, or knowledge production, is expected to be done at university. However, it is an open secret that university is actually a place where the great minds of Africa are enslaved. Stanley Fish (2007) reviewed Evan Coyne Maloney's film, Indoctrinate $U$, and he has good critique on both the film and the broader effort to which it belongs: "As an on-camera presence, Maloney is polite, unflappable and relentless." Fish elaborates:

He borrows some techniques from Michael Moore, but rather than resembling a giant donut, Maloney has the lean boyish looks that could earn him a role in 'Oceans 14', alongside Brad Pitt and Matt Damon. So when he ambles into a university office in search of an administrator who will explain why there is no Men's Resource Center at a university where the Women's Resource Center flourishes, a viewer is likely to ask, Why won't they even talk to that nice young man? (Of course it's a set-up; Maloney knows in advance that no one who works for a large institution is going to start talking to a film crew that just wanders in, and he's counting on it.) 
The thesis of 'Indoctrinate U' is contained in its title. You may think that universities are places where ideas are explored and evaluated in a spirit of objective inquiry. But in fact, Maloney tells us, they are places of indoctrination where a left-leaning faculty teaches every subject, including chemistry and horticulture, through the prism of race, class and gender; where minorities and women are taught that they are victims of oppression; where admissions policies are racially gerrymandered; where identity-based programmes reproduce the patterns of segregation that the left supposedly abhors; where students and faculty who speak against the prevailing orthodoxy are ostracised, disciplined and subjected to sensitivity training; where conservative speakers like Ward Connerly are shouted down; where radical speakers like Ward Churchill are welcomed; where speech codes mandate speech that offends no one; where the faculty preaches diversity but is itself starkly homogeneous with respect to political affiliation; where professors regularly use the classroom as a platform for their political views; where students parrot back the views they know their instructors to hold; where course reading lists are heavy on radical texts and light on texts celebrating the Western tradition; where the American flag is held in suspicion; where military recruiting personnel are either treated rudely or barred from campus; where the default assumption is that anything the United States and Israel do is evil.

A simple example in our context attests to this. Some of us buy food daily at a cafeteria and even get food during Unisa events. The employee at the cafeteria is black, but the food cannot be said to be African. This observation and analysis expose that the ethics of whether food is good or bad, right or wrong, cannot be said to be black. But we have normalised that; it is standard. One, therefore, has to admit that institutional memory is white. Asante (2011:1) shares the same view, arguing that:

Actually these colonial schools were first established to educate Europeans who were distant from their mother countries and felt a need to continue to pass down information that had preserved their societies in their original European habitat. The problem is that often when they left, they left us with their institutions and we were often too afraid to change what we had been given. Indeed, we thought that the system, with its monuments, statues, and rituals of curricula and examinations, was far superior to anything that we could have conceived, and we forgot everything that we had ever conceived. Failure to realise that the modern European university is a creation of Wilhelm von Humboldt, one of Europe's most authentic racists who believed in the superiority of the Aryan and Nordic people over others meant that we could not anticipate the destruction that the curricula of Europe would have on our minds. What type of university do you think would have excited Von Humboldt who taught at Göttingen? It was Von Humboldt who came up with the idea that culture meant cultivation, that is, to have culture one must cultivate it, hence the need for the university. This conception was not that of the Europeans such as Schelling, Herder, Schiller, Fichte or Hegel, who actually believed in the notion of culture as the spirit of the people, the essence of the nation, the soul of the folk. No person could be without it and remain within the group. Culture was what made a people a people in their view. They also formulated hierarchies of culture and got the world to believe in them. However, the notion of cultivation of culture, one aspect of this discourse, led to the creation of institutions that could cultivate the mind and the feeling, making European students more European and Asian and African students imitations of the Europeans. 
Hence, the European university was born as a modern European institution, and I shall add, long after the schools of learning that had existed in ancient Africa and Asia.

Therefore, we need to look beyond our subconscious state to discover the black state of ethics. Black ethics includes a critical tradition of mythological refinement, as white ethics is taught as a position and not debatable, therefore denying blackness any space and augmentation. There is no representation, or less representation, of the black worldview in the institution. In fact, white ethics positions itself as a canon, "the list of works considered to be permanently established as being of the highest quality" (Oxford). Institutional standards are determined under the barometer of this canon, leaving the black worldview marginalised at every corner, and will be eternally and scientifically enslaved to the West. In actual fact, higher education in South Africa is still a legacy of colonial and apartheid education. The fact that I now present in English attests to the fact that Africans are imprisoned in language. This cannot be treated as a coincidence but it must be clear that this is the designed end product and its telos is:

Racism by consequence, operates at the macro-level of society, and represents an historical evolution. It constitutes a gradual shift away from a conscious, almost personalized conviction of the inferiority of an 'othered' 'race'. Such conviction expresses itself in attitudes of prejudice and is acted out in discriminatory behavior. In its place follows social practices that are essentially depersonalized through institutionalization. As a result, racial prejudices may decline overtime, yet more subtle patterns of discrimination persist, supported by the inertia of custom, bureaucratic procedure, impersonal routine, and even law. The result of racism by intent has over time informed institutional cultures and practices that rest on assumptions of white superiority over non-white ethnic group (Guess, 2006:651-652).

It must then be said that institutional racism (or structural racism or systemic racism) refers to a form of racism which occurs specifically in institutions such as public bodies, corporations, and universities. It includes the policies and practices embedded in conventional institutions, which has as consequence the segregation or preferment of designated groups. It manifests itself generally in three ways: firstly; it derives from individuals carrying out the dictates of others who are prejudiced or of a prejudiced society. Secondly; it presents itself in fundamental inequalities embedded in the system-wide maneuver of a society that excludes substantial numbers of members of particular groups from substantial partaking in key public institutions. Thirdly, certain methods of institutional racism may be more unambiguous or informal (for some) to detect than others. Institutional racism still rages and Unisa is not an exception and this is deduced from its 26 March 2008 declaration entitled "The Unisa Statement on racism, racial discrimination and all forms of intolerance" that states:

In the new Unisa, however, we are very conscious that that has not translated into spaces of freedom and belonging by all in our university. We realise that the roots of racism are deeply embedded in the social fabric of our society, rooted in the learned social values and behaviour patterns, and in the persistent power relations that continue to define relations of inequality even in our institution. Racism is pervasive. It mutates in subtle and subliminal forms. Whatever the form, racism hurts. We recognise that the social organisation that we have become all too comfortable with creates barriers to the recognition of the 'other' and to a full appreciation of the humanity of the 'other'.For an academic institution, however, the challenge and the pain are even 
morepalpable because they are inimical to the values of academic freedom, the pursuit of knowledge, and the search for the truth on which any academic institution is founded (sic) .

\section{The Truth through Metaphors}

White ethics, or to use the metaphor of my title, 'a white mist', is, therefore, in the eyes we use to measure our standards. This metaphor of a 'white mist' is very crucial and critical. Mist is a slow drizzle that blurs, and distorts our vision and perception; it prevents us from seeing clearly. Mist is that discomforting confusion that we must wade through just prior to experiencing clarity. The usage of the metaphor for South Africa serves as a direct attack on white racism that says (?): "Lord, make me know my end and what is the extent of my days; Let me know how transient I am" (Psalm 39:4). We must understand the preceding sentence from the perspective of Crawford (2013) that states that: "Biblical metaphors describe life as a mist, a fast runner, a breath and a wisp of smoke". This makes it clear that metaphors are not new in theological circles. Konsmo (2010:198) concludes: "The Pauline Spirit-metaphors fall well within the boundaries of acceptable, appropriate usage of metaphor during the life of the Apostle. The ubiquity of Paul's metaphors, even Spiritmetaphors makes clear the necessity of formal sense; Paul clearly belonged in the Asianist camp of rhetoric that placed less restriction upon the usage of metaphor than the Atticists."

It must be noted that metaphors are conceptual by nature. They are not mere words used in a non-literal sense, "rather, metaphors are conceptual devices used for important cognitive jobs. One of these is that metaphors can actually 'create', or constitute social, cultural and psychological realities for us" (Kovecses 2007:17). It is possible to disagree on the usage of metaphors, including the phrasing of my title; this is nothing new. Dunn (1978:134) argues that:

[T]ime and again in the history of Christianity the cross and currents of theological controversy have thrown a particular word or phrase to the surface where it is tossed back and forth by the waves and becomes the focus of disagreement and dispute. It need not to have been a very significant phrase to earlier generations, but then one side in a debate perceives its usefulness as an expression of their viewpoint and raises it aloft as their banner, while the other side attempts to seize it for themselves or to knock it down. We may recall, for example, the opposing war cries, 'homoousios' and 'homoiousios', the Reformation affirmations 'justification by faith', 'sola scriptura', the Catholic clinging to 'apostolic succession' and 'historic episcopacy', or the fundamentalists' insistence on 'inerrancy of the Bible' and 'substitutionary atonement'.

And since that we will not agree on why the phrase of the title is as it is and on the metaphor of 'white mist', there may be a follow-up question. In the context of South Africa 'race is everything' (Robert Knox in Babb, 1998) and since it is everything it can, therefore, be a mist; whiteness can be described as a mist. It is thus important to take cognisance of the argument of Babb (1998:8-9) that:

It seems ironic how visible and yet invisible whiteness is in the culture of the United States. Terms such as non-white and people of color, which lump many racial and ethnic identities together while implicitly contrasting them to a racial norm, indicate the cardinal nature of whiteness; yet, often discussions of race do not examine the assumptions, practices, and attitude that form its content.

Therefore, it must be clarified that metaphors are more than physical appearances and so whiteness "... is more than a classification of physical appearance; it is largely an invented construct blending history, culture, assumptions and attitude" (Babb, 1998:10). It is for this 
reason that Frankenberg (1993:1) characterises whiteness in the following manner: "[W]hiteness is a location of structural advantage, of race privilege ... [I]t is a 'standpoint', a place from which white people look at ourselves, at others, and at society". Therefore, whiteness transcends appearance, thus positioning itself as a system of privileges accorded to those with white skins. Whiteness then translates itself into an ethics of some type, especially for black society.

As Williams (2012) states:

[T]he problem is essentially the same in our African homeland. There, too, white is still the standard of excellence, of what is right, wise and best. I personally know a number of African presidents and ministers who will not dare to make important decisions without the guidance of white advisors, men who often know far less about the questions at hand than the presidents and their ministers. But they all feel the need for a white seal of approval.

The white seal of approval thereby imposes on blacks a subjective test and conclusion, as they are arrested within a particular tradition that denies their objectivity and places them in a mode of silence. By embracing 'white ethics', blackness loses its ethics to the outside world; that world then becomes a measure and, therefore, normalises a state of confusion for blacks. It is very important to heed the observation made by Williams (2012) when he argued:

Other leaders, equally ignorant of their heritage, simply do not know which way to lead. They, too, feel compelled to adopt and follow Caucasian ideologies because they do not feel free, equal and competent enough to develop an ideology of their own, an Africanoriented ideology. Hence, many, including some black youth leaders from whom so much was expected, are jumping out of white capitalist democracy's frying pan straight into white communism's fire. Neither system was designed for the black world, yet each is only too anxious to use the Blacks as they have always been used: A numeric power for white rule.

I must pause and reiterate that my critique of capitalism also applies to communism, including socialism:

... it would be wrong to categorise and reduce the argument as asking for socialism or promoting socialism as if Africans have no concept of life. The proposal of socialism or communism as a remedy to our situation and problems can never fully solve our African challenges. After all, both systems were designed for a particular course, context and community. It will also be false claim that our answers are to be found in purely foreign ideologies that are rooted in a certain worldview and that carry the risk of assimilation and re-colonisation (Senokoane, 2012:83).

Williams' warning (2012) should in fact be taken seriously, as:

In each case we have not a theory or speculation, but a plain operating fact that even fools can see: Both capitalism and communism have ruling classes that suppress and exploit the people. The masses of people, like so many masses of puppets, are fed and filled with the ideals and principles of both systems. For these they fight and die, screaming these ideals as though they were drugged. Voting creates an illusion of power that does not exist in fact. It works wonderfully well for the rulers, the real decisionmakers, because the people in capitalist democracies actually believe they are deciding and running things. One surprising difference between capitalistic and communistic countries is that the people in the latter countries know they are powerless. 
So, running to a white doctor for an African-diagnosed problem will not lead to cure. Our prescription is found in our worldview. Black ethics are also embedded in the black worldview, ideas and beliefs of what is right or wrong, what is good or bad character. It is also embedded in the conceptions of equal social relations and attitude held by members of society. Moreover, it is embedded in the forms or patterns of behaviour that are considered by the members of black society to bring about social revolution, justice and fairness.

The idea of black ethics has not been given elaborate investigation and clarification; it thus stands in real need of profound and extensive analysis and interpretation. But we can only do this if we push, propose, develop and promote black ethics with the understanding that "[B]lack liberation from white oppression is the fundamental issue" (Roberts Sr, 1975:83). Racism in South Africa has denied a black ethics because it (black ethics) promises blacks their dignity and their identity after a period of disregard. "In different periods, a variety of symbols, laws and institutions have been mobilised to sustain the concept of whiteness, and over time, repeated representations have cemented its identity" (Babb, 1998:16).

The cementing of white symbols has also been hidden in the concepts of equality for all and humanity. Many whites want blacks to believe that there is now racial, political, social, economic, etc. equality in South Africa, but what they will not say is that white supremacy is the basis on which this system has been built. The message must be sent that blacks intend to smash and defeat whiteness. Blacks intend to raise themselves from inferior positions that have been imposed on them, so that when that day comes that race is no longer a measure and we are all called one human race as God has desired - and only then when we meet as human beings we meet as equals: but it is very clearly not yet Uhuru. But since most whites claim that we are one race called human, I must ask the question of Leo Muhammad: "When did I become a human being [to you]?" The motivation of West (1982:48) why blacks are suddenly human beings is very important to grasp: he argues that "the true notion that black people are human beings is a relatively new discovery in the modern West. The idea of black equality in beauty, culture and intellectual capacity remains problematic and controversial within prestigious halls of learning and sophisticated intellectual circles."

But we must be clear and understand that 'humanity' refers to the buzzword 'integration'. Suddenly whites are crying to integrate with blacks, but history and the present inform blacks that the only instances when whites welcome integration are "... when the outcome would put them in a more dominating position, or one of personal security, money and a prestige they could never otherwise achieve" (Williams, 2012). Even the stupid black can realise this. I say 'stupid' because that is what whites think of us. No matter how intelligent, qualified or experienced blacks are, they are still viewed as stupid by whites.

We must refuse to be 'human'. Blacks must refuse neutral and silent conceptions of race because "the resistance to naming white privilege and the scholarly silence that has precluded the analysis of this racial category are the results of whiteness being presumed the norm" (Babb, 1998:15). It is for this reason that some of the cream of the crop, some black leaders, “... unlike the Jews, do not know what their heritage is. They are almost wholly ignorant of their own cultural source from which independent, original thinking springs and progress is inspired" (Williams, 2012). We must conscientise our cream of the crop: "We have a rich ethical and religious tradition, which is rooted in our African 
ancestry and which is the foundation for all the survivals of this heritage in the black religious tradition" (Roberts $\mathrm{Sr}, 1975: 73$ ).

\section{Black Theological Ethics}

One would ask about the interest of a black theologian in ethics and race. It is, therefore, important to present as an example that "[R]acism, however, is not only a moral problem; it is theological as well” (Roberts Sr, 1975:69). In fact, as Roberts Sr. (1975:71) concludes: "All theology is ethical and ethics is theological."

My submission for a black ethics is inspired by the exclusion of blackness in white ethics. White ethics tells us that it is good to have a white leader but bad to have a black leader. It tells us that it is a sign of success to have a rich white, and therefore good, but it is a sign of corruption to have a rich black. It tells us that it is good to have racism, yet bad to have affirmative action. Thus 'white ethics' is not in a position to question itself. According to James Cone (1970:203):

Because White theology and ethics have not asked this question, we concluded that they need to be liberated; that is, freed from the bondage of Whiteness as defined by the variant manifestation of racism. Theology and ethics need to undergo a revolutionary transformation so that the meaning of Christ and his church can be defined in the light of the weak and helpless rather than according to the economic and political interests of oppressors.

It is then clear that religion and black ethics cannot be divorced, as "God is held by the African people not only to be the overlord of the human society but also to have a superbly moral character and because the ancestors [ancestral spirits] are also supposed to be interested in the welfare of the society [they left behind]" (Gyekye, 2013:223). The interest of ancestors in those they have left behind is motivated by a black ethics (as a component of African ethics), as it has similar characteristics to an ethics of duty. A principle of duty is one that requires each entity to exhibit alarm for the interest of others. Campbell (1992:45) attests to this when he states that: "A native will give his best house and his evening meal to a guest, without the slightest thought that he is doing anything extraordinary." And if black ethics can be developed as a mode of conduct for Unisa, we will not have a cry by whites that it is reverse racism because they will be bound to have an interest in black matters. And, once more, our true humanity consists precisely in our creation as black. We shall never be able to gain better human relations until whites have learned to accept blacks as black persons, and to give themselves in service to them (Boesak, 1984:15).

Whites must admit that colonialism and apartheid disadvantaged and excluded blacks, therefore, it is good to have blacks appointed, especially in key positions, and this must be accellerated. Whites must stop thinking only of their own welfare and what is good for them. They must start to think of what is good for blacks. Actually, whites must be warned against their continuous claims, as whenever there is an intention to do good for blacks they claim reverse racism because "when they cry, Racism in reverse! Or reverse discrimination and reverse segregation, they are saying, in effect, that only we whites may discriminate or segregate but not you Blacks!" (Williams, 2012).

It must also be clarified that whites are actually irritated by colourtalk. The black feminist pronouncement on colourtalk is that while it "... may offend some white people as 
not meeting standards of 'niceness', it is far more important that the white people 'hear' the black anger" (O'Connor, 2012:1). Senokoane (2013:13) exposes the anger of blacks: "It has to be clarified that white power was designed as an answer and advancement of white racism, at the same time, the dehumanising and breaking of a black man". In academia, blacks are discouraged from identifying as members of an academic group. Actually, the problem we find is that blacks in academia are 'stigmatised' as less qualified, less experienced, less educated, performing less well, etc. And Stubblefield (200:112) is correct to state that "... stigmatisation of black people by people in positions of social power over them and that a society in which anti-black oppression occurs is white supremacist".

\section{Conclusion}

The article has engaged the roots of black exclusion in intellectual circles, specifically in academia. The academic oppression, exclusion and stigmatisation of blacks compel black academics to be militant and to develop revolutionary consciousness. Black revolutionary consciousness must aim at arming black academics with revolutionary ideology and organisation. Our ideology must be a product of blacks in the struggle for progress and development and against all forms of academic colonialism, academic imperialism and academic apartheid. It must reflect the aspects of black value, humanism, collectivism and egalitarianism and incorporate the positive aspects of their historic experiences with this core ethics. I concur with Sekou Toure (2011) that:

Without revolutionary consciousness there is no Revolution. All those who have conducted revolution agree on this. But where does this revolutionary consciousness come from, since it is certain that it is not basic datum, nor does come into being and develop spontaneously? History teaches us it is created and developed through ideological education and revolutionary practice.

From slavery to apartheid, both designed to exclude and exploit blacks, no ethics but white ethics ever existed. And it is for this reason we need the black academic revolution, because revolution is a complete shift in the ethics and values prescribed by the white world, which will never happen voluntarily. The black academics must push for an academic revolution, and for this to happen they must be informed by a revolutionary theory and revolutionary action. Academic revolution cannot be romantic but has to be violent, and "we cannot say violence is all right when the oppressor uses it to maintain or preserve 'order', but wrong when the oppressor uses it to overthrow this same 'order"' (Gutierrez 1979:28). The black academic must lose his or her fear and attack the white world. It has to be clear that in fact the white world has brought us all the problems black academics are facing today. And it is for this reason I am calling for black ethics, so that black academics can view the world from their own experiences. The point of departure for a black ethics is freedom and not slavery. The struggle for developing black intellectuality must be encouraged by educating blacks, and should be sustained. We must realise that our ideas create our destiny and everything we wish to do begins in our minds. The creation of our own ideology starts by questioning the white worldview, with all its values and beliefs that have been held as a norm and sacred. My last message to those who do not think that there will ever be revolution:

Those who had begun to convince themselves that the fires of popular protest against social repression had been extinguished are beginning to grow uneasy. What looked like defeat will be shown to have been but one episode in a long struggle. In this struggle there will be other setbacks; but there will be new, more decisive advances, as well. For 
this process of popular self-liberation is deeply, securely irreversible (Gutierrez 1979:82).

The time for the black academic to rise is clearly now, in our lifetime. But this can only happen if we are violent against the white structures and systems that declare to blacks that the world can only be named, defined and explained by world barometers. The black world must name, define and explain itself.

\section{BIBLIOGRAPHY}

Asante, A 2011. The Philosophical Bases for an African University: A Curricular for Selfdetermination. Penang, Malaysia. June 27-29.

Babb, VM 1998. Whiteness Visible: The Meaning of Whiteness in American Literature and Culture. New York and London: New York University Press.

Baldwin, J 2014. Collected Essays at http://www.nytimes.com/books/first/b/baldwinessays.html accessed 30 January 2014.

Biko, S 1978. I write what I like. Oxford: Heinemann.

Boesak, AA 1984. Black and Reformed: Apartheid, Liberation, and the Calvinist Tradition. Maryknoll: Orbis Books.

Cone, J 1970. Black Power, Black Theology and the Study of Theology and Ethics. Theological Education 6 (Spring):203.

Ahmed Sekou Toure 2011. Strategy and Tactics of the Revolution: Forward. pp. 13-15.

Accessed at http://media.biola.edu/jseconf/downloads/3013-conference/

dj-crawford.pdf

Campbell, D 1922. In the Heart of Bantuland: A Record of twenty-nine Years in Central Africa among the Bantu Peoples. London: Seely Service and Co.

Dunn, JGD 1978. 'The Birth of a Metaphor - Baptized in Spirit'. Expository Times 89, 1977-78:134-38,173-75.

Frankenberg, R 1993. White Women, Race Matters: The Social Construction of Whiteness. Minneapolis: University of Minnesota Press.

Fish, S 2007. "Yet Once More: Political Correctness on Campus", (October 14). The New York Times at http://opinionator.blogs.nytimes.com/2007/10/14/yet-once-morepolitical-correctness-on-campus/?_php=true\&_type=blogs\&_r $=0$

Guess, TT 2006. The Social Construction of Whiteness: Racism by Intent, Racism by Consequence. Critical Sociology 32 (4). Leiden: Koninklijke Brill NV.

Gutierrez, G 1979. The Power of the Poor in History. Lima, Peru: Centro de Estudios y Publicaciones.

Gyekye, K 2013. Philosophy, Culture and Vision: African Perspectives. Accra:

Sub-Saharan Publishers.

Konsmo, E 2010. The Pauline Metaphors of the Holy Spirit: The Intangible Spirit's

Tangible Presence in the Life of the Christian. New York: Peter Lang Publishing, Inc.

Kovecses, Z 2000. Metaphor and Emotions: Language, Culture and Body in Human Feeling. Cambridge: Cambridge University Press.

Lock, G 1999. Blutopia: Visions of the Future and Revisions of the Past in the Work of Sun. Durham: Duke University Press. 
Morrison, T 2014. At http://thesunmagazine.org/issues/403/sunbeams accessed on 18 March 2014.

O’Connor, T 2012. "Minority Ethics", MegaLinks in Criminal Justice. Retrieved from http://www.drtomoconnor.com/3300/3300lect07a.htm

Oxford Dictionary Language Matters: http://www.oxforddictionaries.com/definition/ english/canon accessed on the 20 January 2014.

Roberts Sr. JD 1975. "Black Theological Ethics: A Bibliographical Essay". Journal of Religious Ethics, 3(1):691-09.

Sekou Toure at: http://www.aaprp-intl.org/revolutionary-consciousness.

Senokoane, BB (Tumi) 2012. My Body, My Business: Das Kapital. Journal of Gender and Religion in Africa Vol. 18 No. 1, July 2012:81-100.

Senokoane, BB (Tumi) 2013. Frank Talk: Black Theology at the Cross-roads. LAP Lambert Academic Publishing.

Stubblefield, A 2005. Ethics along the Color Line. Ithaca, NY: Cornell University Press.

The Unisa Statement on Racism, Racial Discrimination and all Forms of Intolerance. At: http://www.unisa.ac.za/contents/about/principle/docs/Unisa\%20Statement\%20on\%2 0Racism\%20GS.pdf. Pretoria, 26 March 2008.

West, C Talk, Cornell West Flanks the President by Andrew Goldman. July 22, 2011. The New York Times at: http://www.nytimes.com/2011/07/24/magazine/talk-cornelwest.html?_r=0

Williams, C 1974. The Black World at the Crossroads, in The Destruction of Black Civilization at http://africanbloodsiblings.wordpress.com/2012/01/02/excerpt-fromthe-black-world-at-the-crossroad-in-the-destruction-of-black-civilization-1974-bydr-chancellor-williams/ accessed on 18 March 2014. 